\title{
THE ORGANIZATIONAL COMMITMENT AS PERCEIVED BY THE STAFF MEMBERS OF THE FACULTY OF EDUCATION, UNIVERSITY OF KHARTOUM
}

\author{
Saifaldin Idris Onia \\ Department of Educational Administration, Faculty of Education, \\ University of Khartoum, Sudan \\ Email: saifdldom07@gmail.com
}

DOI: http:// doi.org/10.33650/al-tanzim.v5i2.2112

\begin{tabular}{l|l|l} 
Received: April 2021 & Accepted: July 2021 & Published: August 2021
\end{tabular}

\begin{abstract}
:
Organizational commitment is considered an essential concept for ensuring work and staff motivation in a higher education setting. Therefore, this study aimed to assess the staffs' degree of organizational commitment to the Faculty of Education, University of Khartoum. To investigate research questions, a survey questionnaire was conducted. Among 239 respondents, 106 staff members were surveyed (44.00\%). The results indicated that the degree of staff affective, continuance, and normative commitment in the Faculty of Education, University of Khartoum, was high. This study also confirmed that the aggregate degree of organizational commitment among staff members in the Faculty of Education, University of Khartoum, was high. The study revealed no statistically significant difference in the degree of organizational commitment due to gender and academic rank variables. The study also found a statistically significant difference in affective and normative commitment in the degree of organizational commitment related to years of service. The study recommended improving the worldly position of the staff member to maintain a high degree of responsibility at the University of Khartoum.
\end{abstract}

Keywords: Organinization, Commitment, Staff Members

\begin{abstract}
Abstrak:
Komitmen organisasi dianggap sebagai konsep penting guna memastikan motivasi kerja staf di lingkungan pendidikan tinggi. Oleh karena itu, penelitian ini bertujuan untuk menilai tingkat komitmen organisasi staf terhadap Fakultas Ilmu Pendidikan Universitas Khartoum. Untuk menjawab pertanyaan penelitian, kuesioner survei dilakukan. Dari 239 responden, 106 anggota staf yang disurvei (44,00\%). Hasil penelitian menunjukkan bahwa tingkat komitmen afektif, continuance, dan normative staf di Fakultas Ilmu Pendidikan Universitas Khartoum tergolong tinggi. Penelitian ini juga menegaskan bahwa tingkat agregat komitmen organisasi di antara anggota staf di Fakultas Pendidikan, Universitas Khartoum, tinggi. Studi ini mengungkapkan tidak ada perbedaan yang signifikan secara statistik dalam tingkat komitmen organisasi karena variabel gender dan peringkat akademik. Studi ini juga menemukan perbedaan yang signifikan secara statistik dalam komitmen afektif dan normatif dalam tingkat komitmen organisasi terkait dengan masa kerja. Studi tersebut merekomendasikan peningkatan posisi duniawi anggota staf untuk mempertahankan tanggung jawab tingkat tinggi di Universitas Khartoum.
\end{abstract}

Kata Kunci: Organisasi, Komitmen, Anggota Staf 


\section{INTRODUCTION}

Organizational commitment is considered an essential concept for ensuring the continuity of work and staff motivation (Tekin et al., 2014). This organizational commitment was defined as the degree of loyalty, the strength of identification and the responsibility for a shared mission, and the level of commitment and willingness to make efforts to achieve that mission (Mowday et al., 1979; Camp, 1994; Hulpia et al., 2009). The stereotypical view of commitment reflects the loyalty and willingness to work towards organizational objectives (Absar \& Swain, 2010).

According to Meyer \& Allen (1991), organizational commitment is reflected in at least three general topics: active association with the organization, the predictable cost of leaving the organization, and the obligation to remain within the organization. All three methods are referred to as being affective, continuance, and normative. Affective commitment is characterized as the employees' willingness to continue to work on a practical and voluntary basis at that organization. Workers who are so committed to their organizations continue to work there because they "want to," not because they "have to" (Nasiri, 2015). Continuance commitment is an attachment to an organization based on an employee's awareness of the costs of discontinuing membership (Reza et al., 2010). On the other hand, normative commitment reflects the obligation of an employee to remain in his organization (Bryant et al., 2007).

Organizational commitment at universities and research institutions has recently started to attract growing attention (Tekin et al., 2014). Altbach (2006) explained that staff, particularly academic staff, are key players in achieving the mission, objectives, and responsibilities of higher education institutions. Oludeyi (2015) confirmed that higher education institutions are therefore more dependent on their staff's intellectual capital, creative skills, and commitment. Wainaina (2015) stated that engaged staff are less likely to leave for another job and are more likely to perform at higher levels. To this end, the overall performance of universities depends upon their academic staff' and, ultimately, their level of commitment (Kassaw \& Golga, 2019).

The degree of staff commitment is a crucial tool for predicting whether staff will leave an organization soon or is willing to stay longer (Bin Jomah, 2017). However, some scholars have looked at the staff's organizational commitment, such as; Lorch (2019) attempted to establish predictors of corporate participation in community college faculty, using Meyer and Allen's three components of this commitment. The data showed high rates of organizational commitment from those studied, suggesting that Arkansas faculty is significantly different from national trends in a positive manner. Kassaw \& Golga (2019) carried out a study to assess the academic staff's level of organizational commitment. Furthermore, the study evaluated whether there is a significant difference in the level of organizational commitment of academic staff in terms of gender and educational status. The study revealed a moderate level of organizational commitment among academic staff at the university. The study further showed that the level of organizational commitment of academic staff was significantly different concerning their educational level. 
Koc (2018) aimed to demonstrate the correlations between academicians' organizational commitment and their intention to resign from their job. The study found that the level of organizational commitment was high, and they had the most emotional commitment, followed by normative commitment and continuing commitment. Koul (2016), in his study, examined the teachers' organizational commitment levels in select Government Colleges of Chandigarh. Commitment ratings for substantive participation were the highest. No significant difference between male and female teachers was observed for their level of commitment. Also, teachers' commitment levels did not vary depending on their qualifications and years of service. Fika, Ibi, \& Abdulrahman (2016) carried out a study to determine the level of staff commitment in Borno State Colleges of Education. The study results showed that the level of commitment of staff at Borno State Colleges of Education was low.

Gamer (2015) conducted a study to investigate the relationship between organizational commitment and job satisfaction among staff members at Dongola University, and then to the effect of some variables (gender, years of experience, age, academic qualification). Results showed: organizational commitment and job satisfaction were high degrees. Also, there are no statistically significant differences in organizational commitment and job satisfaction differences due to the variable gender. There are statistically significant in organizational commitment and job satisfaction due to the unstable years of experience differences in favor of 11 years and over. There are also differences in organizational commitment attributed to the educational qualification variable in turn of teaching assistants.

Tekin, Kayacan, \& Bektaş (2014) investigated the organizational commitment of scholars employed in several public universities. The analysis results revealed a statistically significant difference between the female and male groups concerning continuance commitment. Yahaya, Chek, Samsudin, \& Jizat (2014) designed a study to investigate the level of organizational commitment in a Malaysian public higher education. Overall, the result revealed that the commitment level of faculty members was high; the majority $(87.7 \%)$ of the respondents were classified as very committed (a score between 68 and 105). The results also revealed no significant difference between male and female faculty members regarding their level of organizational commitment.

Despite the profound and far-reaching changes that exist in the world's economic and social system and the new definitions that have been presented about the relationship between the individual and the organization, the concept of commitment is still the subject of many management articles and studies (Haftkhavani et al., 2012). Research into organizational commitment demonstrated that maintaining a high level of organizational commitment is one of the most important predictors of many desirable organizational outcomes (Garipağaoğlu, 2013). Similarly, organizational commitment is a factor that can be considered a measure of an organization's success, and many research findings indicated that a lack of organizational commitment could 
reduce organizational effectiveness (Banjarnahor et al., 2018). That's why organizational commitment is essential in any organization, because highly organizationally committed employees can demonstrate positive work behaviors (Selamat \& Nordin, 2012). It is also widely accepted that committed employees work harder and are more likely to make additional efforts to achieve organizational objectives (Meyer \& Allen, 2004).

However, although some researches were conducted on staffs' commitment to higher education, there was no much sound evidence of assessment of staffs' level of organizational commitment, particularly in the University of Khartoum. Thus, staffs' organizational commitment has been still one of the pressing issues in many Universities of Sudan, which has not yet been well addressed. Therefore, the researcher was reinforced to fill such a gap by focusing their investigation on the following fundamental research questions; 1) What is the degree of organizational commitment as perceived by staff members in the Faculty of Education, University of Khartoum ?; 2) Does the organizational commitment differ based on staff members' gender, academic rank, and years of service?

\section{RESEARCH METHODS}

The study used survey research designs. Survey research designs are procedures in quantitative research in which investigators administer a survey to a sample or to the entire population of people to describe the population's attitudes, opinions, behaviors, or characteristics (Creswell, 2012). Survey research was used in this study because the topic or problem under investigation, not much is known yet about it. So, the researcher wants to identify characteristics, frequencies, and categories of the variable of interest at the University of Khartoum.

Therefore, from the total population 239 of staff members, a sample size of 106 respondents was optimal for this study, which represents $(44.00 \%)$. The staff members were selected by stratified random sampling because, in this type, all population members stood a chance of being selected. The stratification variable of interest is the sex of staff members, with two subgroups - male and female. The researcher classified staff members into subgroups. Of the 239 staff members, $49 \%$, or 117 , are male staff members, $51 \%$, or 122 , are female staff members. Because we want proportional representation, $49 \%$ of the sample (52 staff members) were male staff members, and 51\% (54 staff members) were female staff members.

To answer the research questions, the researcher used a revised version of the organizational commitment scale by Meyer, Allen, and Smith (1993), a standardized questionnaire consisting of three dimensions: affective commitment, continuance commitment, and normative commitment. Affective commitment measures the desire of staff to remain with the university. Normative commitment measures the obligation of staff to stay in the university. Continuance commitment measures recognition of the costs of leaving the university. Respondents were asked to rate on a five-point Likert scale $(1=$ strongly disagree, five = strongly agree) used for all items under 
organizational commitment, which comprises 18-items (six items for each dimension of organizational commitment). This questionnaire contains some negative items that were reversed as $(1=5$ "strongly agree", $2=4$ "agree", $3=3$ "partially agree", $4=2$ "disagree", $5=1$ "strongly disagree").

The reliability of the questionnaire was assessed using Cronbach's alpha coefficient. The reliability for the overall organizational commitment and its sub-scales satisfied the acceptable criteria ( $r=0.70)$. According to Katou (2008), the questionnaire will consider reliable if the Cronbach's Alpha coefficient is more significant than 0.70 . The Cronbach's alpha of subscales was found to be 0.69 for continuance commitment, 0.73 for normative commitment, and 0.76 for affective commitment. The composite Crobancha's alpha of organizational commitment was 0.718. This means that the result of the reliability was acceptable; therefore, the questionnaire was valid to be applied.

\section{RESULTS AND DISCUSSION}

\section{Demographic Characteristics of Staff Members}

Participants' demographic characteristics have provided basic information about their distribution based on gender, academic rank, and years of service.

Table 1 : Demographic Characteristic of Participants

\begin{tabular}{|c|c|c|c|}
\hline Variables & Categories & Frequency & Percent \\
\hline \multirow{3}{*}{ Sex } & Male & 52 & 49.1 \\
\hline & Female & 54 & 50.9 \\
\hline & Total & 106 & 100.0 \\
\hline \multirow{6}{*}{ Academic Rank } & Professor & 3 & 2.8 \\
\hline & Associate Professor & 14 & 13.2 \\
\hline & Assistant Professor & 44 & 41.5 \\
\hline & Lecturer & 34 & 32.1 \\
\hline & Teaching Assistant & 11 & 10.4 \\
\hline & Total & 106 & 100.0 \\
\hline \multirow{4}{*}{ Years of service } & Less than 5 years & 18 & 17.0 \\
\hline & $5-10$ years & 32 & 30.2 \\
\hline & Over 10 years & 56 & 52.8 \\
\hline & Total & 106 & 100.0 \\
\hline
\end{tabular}

Table 1 shows that the respondent's proportion in sex was $(49.1 \%)$ for males and (50.9\%) for females. In terms of academic rank, most of the staff was assistant professor $(41.5 \%)$ and lecturers (32.1\%) because they are more active in their work. Most of them hold an administrative position with their teaching role, so they were available in the faculty. The few respondents were full professor $(2.8 \%)$, teaching assistant $(10.4 \%)$, then associate professor $(13.2 \%)$. The data in Table 1 also shows that the proportion of respondents increase with an increase in the interval years of service ranging from (52.8\%) with respondents over ten years which is considered very good to enrich the results 
of the study, and (30.2\%) for 5-10 years, to (17.0\%) of those serving less than five years. The implication of these demographic characteristics represents how the category of each variable was considered that resulted in a representative sample of the target population.

\section{The Degree of Organizational Commitment as Perceived by Staff Members}

The degree of organizational commitment among staff members in the Faculty of Education, University of Khartoum, was the first research question. To this end, a one-sample t-test was employed, and the result is shown in Table 2.

Table 2 : One Sample T-test for The Degree of Staff Organizational Commitment

\begin{tabular}{ccccccc}
\hline Variable & Mean & $\begin{array}{c}\text { Test } \\
\text { Value }\end{array}$ & $\begin{array}{c}\text { Std. } \\
\text { Deviation }\end{array}$ & $\begin{array}{c}\text { Mean } \\
\text { Difference }\end{array}$ & T & $\begin{array}{c}\text { Sig. } \\
\text { (2- } \\
\text { tailed) }\end{array}$ \\
\hline $\begin{array}{c}\text { Affective } \\
\text { Commitment }\end{array}$ & 24.47 & 18 & 3.657 & 6.472 & 18.219 & .000 \\
\hline $\begin{array}{c}\text { Continuance } \\
\text { Commitment }\end{array}$ & 18.92 & 18 & 4.644 & .915 & 2.029 & .045 \\
\hline $\begin{array}{c}\text { Normative } \\
\text { Commitment }\end{array}$ & 24.10 & 18 & 3.615 & 6.104 & 17.386 & .000 \\
\hline $\begin{array}{c}\text { Overall } \\
\text { organizational } \\
\text { commitment }\end{array}$ & 67.49 & 54 & 7.407 & 13.491 & 18.752 & .000 \\
\hline
\end{tabular}

$\mathrm{N}=106, \mathrm{df}=105$

The result in Table 2 shows that the mean scores of the affective commitment, continuance commitment, and normative commitment were found to be significantly higher than the respective Test values (18) with $(t=18.219,2.029$, and 17.386) at $p<0.05$. This means the degree of staff effectiveness, continuance, and normative commitment in the Faculty of Education was high. Also, the overall mean score of organizational commitment (67.49) was also significantly more significant than the expected test value (54) with $(t=18.752$ and $\mathrm{p}<.05)$. This means the degree of staff organizational commitment in the Faculty of Education, University of Khartoum was high. This can be explained by the fact that the staff members had a strong sense of belonging to the Faculty of Education, and they would not leave the university right now because they have a sense of obligation to the staff. Also, most of the staff members have graduated from the University of Khartoum and were appointed to the same university, so they feel the university deserves their loyalty.

The result of the study seems to agree with the development of Koc (2018), who found that the level of organizational commitment was high, and they had the most emotional commitment, followed by normative commitment and continuing commitment. Lorch (2019) showed high rates of organizational commitment at Arkansas faculty. Supporting this, Koul (2016) revealed that 
commitment ratings for substantive participation were the highest in select Government Colleges of Chandigarh. Also, Gamer (2015) showed that organizational commitment was high among staff members at Dongola University. Similarly, Yahaya, Chek, Samsudin, \& Jizat (2014) revealed that the commitment level of faculty members was high in a Malaysian public higher education. In contrast with this study's result, Fika, Ibi, \& Abdulrahman (2016) found that the level of staff commitment in Borno State Colleges of Education was low. Also, Kassaw \& Golga (2019) revealed a moderate level of organizational commitment among academic staff at the HaramayaUniversity.

\section{Gender Difference in the Degree of Organizational Commitment}

Mann-Whitney $U$ test was computed to examine whether there is a significant difference in the degree of organizational commitment concerning gender. To see differences between male and female participants in their overall loyalty and three dis-aggregated commitment dimensions, the results were summarized and presented in Table 3.

Table 3 : Mann-Whitney U Statistic for Gender Differences in the Degree of Organizational Commitment

\begin{tabular}{|c|c|c|c|c|c|c|}
\hline Variable & Gender & $\mathbf{N}$ & $\begin{array}{l}\text { Mean } \\
\text { Rank }\end{array}$ & $\begin{array}{c}\text { Sum of } \\
\text { Ranks }\end{array}$ & $\begin{array}{c}\text { Mann- } \\
\text { Whitney U }\end{array}$ & $\begin{array}{l}\text { Sig. (2- } \\
\text { tailed) }\end{array}$ \\
\hline Affective & Male & 52 & 50.81 & 2642.00 & 1264.000 & .374 \\
\hline \multirow[t]{2}{*}{ Commitment } & Female & 54 & 56.09 & 3029.00 & & \\
\hline & Total & 106 & & & & \\
\hline Continuance & Male & 52 & 53.44 & 2779.00 & 1401.000 & .985 \\
\hline \multirow[t]{2}{*}{ Commitment } & Female & 54 & 53.56 & 2892.00 & & \\
\hline & Total & 106 & & & & \\
\hline \multirow{3}{*}{$\begin{array}{l}\text { Normative } \\
\text { Commitment }\end{array}$} & Male & 52 & 48.73 & 2534.00 & 1156.000 & .115 \\
\hline & Female & 54 & 58.09 & 3137.00 & & \\
\hline & Total & 106 & & & & \\
\hline \multirow{3}{*}{$\begin{array}{c}\text { Overall } \\
\text { organizational } \\
\text { Commitment }\end{array}$} & Male & 52 & 49.51 & 2574.50 & 1196.500 & .189 \\
\hline & Female & 54 & 57.34 & 3096.50 & & \\
\hline & Total & 106 & & & & \\
\hline
\end{tabular}

As shown in Table 3, the results reveal that the values of Mann-Whitney between 1156.000and 1401.000are significant, where the sig. $>0.05$ for affective, continuance, normative, and overall organizational commitment with their respective $(\operatorname{sig}=0.374,0.985,0.115$, and 0.189 ). This indicates no statistically significant difference between the male and female groups in the degree of organizational commitment. This can be explained by the fact that the male and females have the same feeling of loyalty and belonging to the Faculty of Education, the University of Khartoum, as they work in the same work conditions and receive the same salaries.

This study agrees with the result of Koul (2016) found no significant difference between male and female teachers were observed for their level of commitment in select Government Colleges of Chandigarh. Yahaya, Chek, Samsudin, \& Jizat (2014) revealed no significant difference between male and 
female faculty members regarding their level of organizational commitment in a Malaysian public higher education. The result of the current study is different from Tekin, Kayacan, \& Bektaş (2014), who revealed a statistically significant difference between the female and male groups regarding continuance commitment to public universities in Turkey.

\section{Differences in Organizational Commitment with Reference to Academic Rank}

To assess whether the degree of organizational commitment is significantly different in terms of their academic rank,-way analysis of variance (ANOVA) was computed. The result is shown in Table 4.

Table 4 : ANOVA analysis for Differences among Staff in Terms of Academic Rank

\begin{tabular}{|c|c|c|c|c|c|c|}
\hline Variable & Source & $\begin{array}{l}\text { Sum of } \\
\text { Squares }\end{array}$ & Df & $\begin{array}{l}\text { Mean } \\
\text { Square }\end{array}$ & $\mathbf{F}$ & Sig. \\
\hline Affective & Between & 44.248 & 4 & 11.062 & .821 & .514 \\
\hline \multirow[t]{4}{*}{ Commitment } & Groups & & & & & \\
\hline & Within & 1360.167 & 101 & 13.467 & & \\
\hline & Groups & & & & & \\
\hline & Total & 1404.415 & 105 & & & \\
\hline \multirow{5}{*}{$\begin{array}{l}\text { Continuance } \\
\text { Commitment }\end{array}$} & Between & 52.201 & 4 & 13.050 & .596 & .666 \\
\hline & Groups & & & & & \\
\hline & Within & 2212.035 & 101 & 21.901 & & \\
\hline & Groups & & & & & \\
\hline & Total & 2264.236 & 105 & & & \\
\hline \multirow{5}{*}{$\begin{array}{l}\text { Normative } \\
\text { Commitment }\end{array}$} & Between & 55.354 & 4 & 13.839 & 1.062 & .380 \\
\hline & Groups & & & & & \\
\hline & Within & 1316.504 & 101 & 13.035 & & \\
\hline & Groups & & & & & \\
\hline & Total & 1371.858 & 105 & & & \\
\hline \multirow{5}{*}{$\begin{array}{c}\text { Overall } \\
\text { organizational } \\
\text { commitment }\end{array}$} & Between & 149.681 & 4 & 37.420 & .674 & .612 \\
\hline & Groups & & & & & \\
\hline & Within & 5610.809 & 101 & 55.553 & & \\
\hline & Groups & & & & & \\
\hline & Total & 5760.491 & 105 & & & \\
\hline
\end{tabular}

Table 4 shows that the results of $\mathrm{F}$ between 0.596 and 1.062, and there is no difference in the degree of affective, continuance, normative, and overall organizational commitment among staff according to their academic rank as (sig $=0.514,0.666,0.380$, and 0.612 ) respectively which is more significant than 0.05. This indicates that there is no difference in the degree of organizational commitment related to academic rank. This may be because the staff members work in the same work circumstances, as they work under one educational leadership. Supporting the result of the study, Al-Wazrah (2015) showed no significant difference among the study population in the degree of commitment related to the academic rank variable. Koul (2016) found that teachers' 
commitment levels did not vary depending on their level of qualification in select Government Colleges of Chandigarh. In differ with the result of the study; Gamer (2015) revealed differences in organizational commitment attributed to the educational qualification variable favoring teaching assistants at Dongola University.

\section{Differences in Organizational Commitment with Reference to Years of Service}

To assess whether the degree of organizational commitment is significantly different in terms of their years of service,-way analysis of variance (ANOVA) was computed. The result is shown in Table 5.

Table 5 : ANOVA analysis for differences among staff in terms of years of

\begin{tabular}{|c|c|c|c|c|c|c|}
\hline Variable & Source & $\begin{array}{l}\text { Sum of } \\
\text { Squares }\end{array}$ & Df & $\begin{array}{l}\text { Mean } \\
\text { Square }\end{array}$ & $F$ & Sig. \\
\hline \multirow{4}{*}{$\begin{array}{c}\text { Affective } \\
\text { Commitment }\end{array}$} & Between & 89.198 & 2 & 44.599 & 3.493 & .034 \\
\hline & Groups & & & & & \\
\hline & Within Groups & 1315.217 & 103 & 12.769 & & \\
\hline & Total & 1404.415 & 105 & & & \\
\hline \multirow{4}{*}{$\begin{array}{l}\text { Continuance } \\
\text { Commitment }\end{array}$} & Between & 67.067 & 2 & 33.533 & 1.572 & .213 \\
\hline & Groups & & & & & \\
\hline & Within Groups & 2197.169 & 103 & 21.332 & & \\
\hline & Total & 2264.236 & 105 & & & \\
\hline \multirow{4}{*}{$\begin{array}{c}\text { Normative } \\
\text { Commitment }\end{array}$} & Between & 121.644 & 2 & 60.822 & 5.011 & .008 \\
\hline & Groups & & & & & \\
\hline & Within Groups & 1250.214 & 103 & 12.138 & & \\
\hline & Total & 1371.858 & 105 & & & \\
\hline \multirow{3}{*}{$\begin{array}{c}\text { Overall } \\
\text { organizational } \\
\text { commitment }\end{array}$} & Between & 261.118 & 2 & 130.559 & 2.445 & .092 \\
\hline & Within Groups & 5499.373 & 103 & 53.392 & & \\
\hline & Total & 5760.491 & 105 & & & \\
\hline
\end{tabular}

It is evident from Table 5 the p-value (sig. $<0.05$ ) is significance in terms of affective and normative commitment (sig. $=0.034,0.008$ ) respectively. This indicates significant differences between the staff members in these two dimensions. This finding supports Al-Wazrah's (2015) result, who found significant differences among them in the degree of organizational commitment related to the length of experience. To see the source of those differences, the Tukey HSD test was applied, as shown in Table 6. 
Table 6: Tukey HSD to discover the source of differences in terms of years of service

\begin{tabular}{|c|c|c|c|c|c|c|c|}
\hline Variable & $\begin{array}{c}\text { Years of } \\
\text { service }\end{array}$ & Mean & $\begin{array}{c}\text { Less } \\
\text { than } \\
5 \\
\text { years }\end{array}$ & $\begin{array}{c}5-10 \\
\text { year } \\
s\end{array}$ & $\begin{array}{c}\text { Ove } \\
\text { r } 10 \\
\text { year } \\
\text { s }\end{array}$ & $\begin{array}{c}\text { Sig } \\
.\end{array}$ & $\begin{array}{c}\text { Differenc } \\
\text { e favor }\end{array}$ \\
\hline $\begin{array}{l}\text { Affective } \\
\text { commitment }\end{array}$ & $\begin{array}{c}\text { Less } \\
\text { than } 5 \\
\text { years } \\
5-10 \\
\text { years } \\
\text { Over } 10 \\
\text { years }\end{array}$ & $\begin{array}{c}22.4 \\
4 \\
\\
24.8 \\
4 \\
24.9 \\
1\end{array}$ & & & * & 0.03 & $\begin{array}{c}\text { Over } 10 \\
\text { years }\end{array}$ \\
\hline $\begin{array}{l}\text { Normative } \\
\text { commitment }\end{array}$ & $\begin{array}{c}\text { Less } \\
\text { than } 5 \\
\text { years } \\
5-10 \\
\text { years } \\
\text { Over } 10 \\
\text { years }\end{array}$ & $\begin{array}{c}21.8 \\
3 \\
\\
24.1 \\
3 \\
24.8 \\
2 \\
\end{array}$ & & & * & $\begin{array}{c}0.00 \\
6\end{array}$ & $\begin{array}{l}\text { Over } 10 \\
\text { years }\end{array}$ \\
\hline
\end{tabular}

* The mean difference is significant at the 0.05 level.

Table 6 shows a significant difference among staff members in affective commitment between years of service less than five years and over ten years in favor of staff members over ten years $(M=24.91)$. Also, there is a significant difference among staff members in normative commitment between years of service less than five years and over ten years in favor of staff members over ten years $(M=24.82)$. This can be explained by the fact that those who spend more than ten years in the university their loyalty and obligation have increased due to long years of service in the university. Supporting this result of the study, Gamer (2015) revealed a statistically significant difference in the organizational commitment due to the variable years of service in favor of 11 years and over. The result of the current study is different from Koul's (2016) effect, which found teachers' commitment levels did not vary depending on their years of service.

\section{CONCLUSION}

This study aimed to assess the degree of organizational commitment perceived by staff members in the Faculty of Education, University of Khartoum. The study employed a descriptive research approach using the corporate commitment scale by Meyer, Allen, and Smith (1993), a standardized questionnaire consisting of three dimensions: affective commitment, continuance commitment, and normative commitment. Affective commitment measures the desire of staff to remain with the university. Normative commitment measures the obligation of staff to stay in the university. Continuance commitment measures recognition of the costs of leaving the university. 
The results indicate that the degree of staff affective, continuance, and normative commitment in the Faculty of Education, University of Khartoum, was high. The aggregate degree of organizational commitment among staff members at the University of Khartoum was high. Based on the findings, the study forwarded the following recommendations to maintain the high level of academic staff organizational commitment and bring about University success. The study recommended that academic staff pursue short-and long-term planoriented university achievement goals to achieve them cooperatively and effectively. Academic staff should be given due attention through acknowledgment, compensation, and incentive packages to ensure that they perform well in a sustainable manner. The study also recommended improving the worldly position of the staff to maintain a high degree of commitment at the University of Khartoum.

The main limitation of this study is that the data were gathered in one faculty at the University of Khartoum only. Therefore, the findings of the study cannot be generalized to other faculties. But, it can compare with other faculties and other Sudanese higher education institutions, in different locations and at additional other times.

\section{REFERENCES}

Absar, S., \& Swain, R. D. (2010). Organizational Commitment of University Teachers Across Disciplines and Designations: Management and Professionalization of Higher Education. New Delhi: Macmillan Publisher India Ltd.

Altbach, P. G. (2006). Comparative Higher Education: Knowledge and Development. Boston: Boston College.

Al-Wazrah, A., M. (2015). The Degree of Organizational Commitment among Faculty Members in the College of Social Sciences at Imam Muhammad Ibn Saud Islamic University from Their Perceptions (in Arabic). Journal of Education Studies, 332(2265), 1-99.

Banjarnahor, H., Hutabarat, W., Sibuea, A. M., \& Situmorang, M. (2018). Job Satisfaction as a Mediator between Directive and Participatory Leadership Styles toward Organizational Commitment. International Journal of Instruction, 11(4), 869-888.

Bin Jomah, N. (2017). Psychological Empowerment on Organizational Commitment as Perceived by Saudi academics. World Journal of Education, 7(1), 83-92.

Bryant, S. E., Moshavi, D., \& Nguyen, T. V. (2007). A Field Study on Organizational Commitment, Professional Commitment and Peer Mentoring. ACM SIGMIS Database: The Database for Advances in Information Systems, 38(2), 61-74.

Camp, S. D. (1994). Assessing The Effects of Organizational Commitment and Job Satisfaction on Turnover: An Event History Approach. The Prison Journal, 74(3), 279-305. 
Creswell, J. W. (2012). Collecting qualitative data. Educational Research: Planning, Conducting, and Evaluating Quantitative and Qualitative Research. Boston: Pearson, 204-235.

Fika, I. B., Ibi, M. B., \& Abdulrahman, A. (2016). Staff Utilization and Commitment in Borno State Colleges of Education, Nigeria. Journal of Education and Practice, 7(20), 68-74.

Çağla Garipağaoğlu, B. (2013). Examining Organizational Commitment of Private School Teachers. Journal of Educational E Instructional Studies in the World, 3(2), 1-12

Haftkhavani, Z. G., Faghiharam, B., \& Araghieh, A. (2012). Organizational Commitment and Academic Performance (Case Study: Students at Secondary Schools for Girls). Procedia-Social and Behavioral Sciences, 69, 1529-1538.

Hulpia, H., Devos, G., \& Rosseel, Y. (2009).The Relationship Between The Perception of Distributed Leadership in Secondary Schools and Teachers' and Teacher Leaders' Job Satisfaction and Organizational Commitment. School Effectiveness and School Improvement, 20(3), 291-317.

Kassaw, E. S., \& Golga, D. N. (2019). Academic Staffs' Level of Organizational Commitment in Higher Educational Setting: The Case of Haramaya University. International Journal of Higher Education, 8(2), 87-100.

Katou, A. A. (2008). Measuring the impact of HRM on organizational performance. Journal of Industrial Engineering and Management (JIEM), 1(2), 119-142.

Koc, M. (2018). Research on Correlations between Academicians' Levels of Organizational Commitment and Their Intention to Quit Their Job: A Comparison of State and Foundation Universities. Journal of Education and Learning, 7(1), 163-173.

Kothari, C. R. (2004). Research Methodology: Methods and Techniques. 2nd edition. New Delhi: New Age International.

Koul, N. (2016). Evaluation of Organization Commitment of Teachers: A Study in Select Government Colleges of Chandigarh. Journal of Business and Management, 18(12), 11-15.

Meyer, J. P., Allen, N. J., \& Smith, C. A. (1993). Commitment to Organizations and Occupations: Extension and Test of a Three-component Conceptualization. Journal of applied psychology, 78(4), 538-551.

Meyer, J. \& Allen, N. (1991). A Three Component Conceptualization of Organizational Commitment. Human Resource Management Review, 1(1), 61-89.

Meyer, J. P. \& Allen, N. J. (2004). TCM Employee Commitment Survey Academic Users Guide. London: University of Western Ontario.

Mowday, R. T., Steers, R. M., \& Porter, L. W. (1979). The Measurement of Organizational Commitment.Journal of Vocational Behaviour, 14(2), 224247. 
Nasiri, M. (2015). The Survey of Conceptual Modeling of Causal Relationship between Organization Commitment with Organizational Citizenship Behavior in Campus Recreation Administrations. International Journal of Sport Studies, 5(6), 653-658.

Oludeyi, O. S. (2015). Workplace Factors as Determinants of Job Commitment among Senior Non-teaching Staff of (Doctoral Dissertation, University of Ibadan, Ibadan).

Jandaghi, G., Borghei, R., Matin, H. Z., \& Dastani, N. (2010). An examination of the relationship between empowerment and organizational commitment. Journal of Human Sciences, 7(2), 1155-1172.

Selamat, N., \& Nordin, N. (2012, March). A Study On Teacher's Commitment and Emotional Intelligence In The District Of Klang. In Proceedings of the 2nd. International Conference on Arts, Social Sciences E Technology Penang, Malaysia, 3rd.-5th.

Tekin, M., Kayacan, E., \& Bektaş, H. (2014). Organizational Commitment: An Empirical Investigation of Scholars in Turkish Universities. EkonometriveIstatistikDergisi, 21(2), 69-80.

Wainaina, L. W. (2015). Determinants of Organizational Commitment among Academic Staff in Kenya's Public and Private Universities (Doctoral Dissertation).

Yahaya, R., Chek, I. T., Samsudin, N., \& Jizat, J. E. M. (2014). Organizational Commitment at a Higher Education Institution. International Journal of education and research, 2(11), 309-318. 